\title{
Modeling of the intermediary role of psychological capital in the relationship between organizational trust and job performance in the employees of the north-western departments of sports and youths of Iran
}

\section{Hamza Shamhi}

Ph.D Student, Department of Sport Management, Sanandaj Branch, Islamic Azad University, Sanandaj, Iran h.shamhi@yahoo.com

Kourosh Veisi

Assistant Professor, Department of Sport Management, Sanandaj Branch, Islamic Azad University, Sanandaj, Iran koroshveisi@yahoo.com

Kheidan Hatami

Assistant Professor, Department of Sport Management, Sanandaj Branch, Islamic Azad University,Sanandaj, Iran

kiamak_2001@yahoo.com

Samira Aliabadi

Assistant Professor, Department of Sport Management, Sanandaj Branch, Islamic Azad University,Sanandaj, Iran s.aliabadi311@hotmail.com

Editor Científico: José Edson Lara
Organização Comitê Científico
Double Blind Review pelo SEER/OJS
Recebido em 22.01.2019
Aprovado em 21.03.2019

Este trabalho foi licenciado com uma Licença Creative Commons - Atribuição - Não Comercial 3.0 Brasil 


\begin{abstract}
The purpose of this study was to modeling of the intermediary role of Psychological Capital in the relationship between Organizational Trust and Job Performance in the employees of the north-western departments of Sports and Youths of Iran. This research is considered as an applied descriptive-correlational study. The population of the study included the entire 320 employees of the departments of Sports and Youths located in the north-west of Iran. Among the population, 200 individuals were selected as the sample of study through the application of the stratified random sampling method. The required research data have been also collected through the application of three standard questionnaires of Organizational Trust (Alonen et al., 2008), Job Performance (Paterson, 1970), and Psychological Capital (Luthanz, 2007). It is worthy of mentioning that the validities of the questionnaires were approved by sport management professors and reliability of questionnaires with Cronbach's alpha for the questionnaires of organizational trust, JP, and PC were $0.81,0.74$, and 0.79 . For the purpose of analysis of the collected data technics related to descriptive statistics such as abundance tables and diagrams have been used SEM (structural equations modeling), t-tests, and one-way ANOVA were also used in the environments of the SPSS and LISREL software for testing the hypotheses. Results show that OT and JP and OT are related to PC in a positive and statistically significant manner. In addition it was uncovered that OT has influences on the JP of the employees of the departments of Sports and Youths through psychological capital. Additionally, it was found out that there existed no statistically significant relationship between any of demographic features and the main variables of the study.
\end{abstract}

Keywords: Psychological Capital, Organizational Trust, Job Performance, Sports Organizations.

\title{
Modelagem do papel intermediário do capital psicológico na relação entre confiança organizacional e desempenho no trabalho nos funcionários dos departamentos do esporte e juventude do Irã
}

\section{Resumo}

O objetivo deste estudo foi modelar o papel intermediário do Capital Psicológico na relação entre Confiança Organizacional e Desempenho no Trabalho nos funcionários dos departamentos do Esporte e Juventude do Irã. Esta pesquisa é considerada como um estudo descritivo-correlacional aplicado. A população do estudo incluiu todos os 320 funcionários dos departamentos de Esportes e Jovens localizados no noroeste do Irã. Entre a população, 200 indivíduos foram selecionados como amostra de estudo por meio da aplicação do método de amostragem aleatória estratificada. Os dados de pesquisa necessários também foram coletados por meio da aplicação de três questionários-padrão de Confiança Organizacional (Alonen et al., 2008), Job Performance (Paterson, 1970) e Capital Psicológico (Luthanz, 2007). Vale ressaltar 
que as validações dos questionários foram aprovadas pelos professores de esporte e a confiabilidade dos questionários com o alfa de Cronbach para os questionários de confiança organizacional, JP e PC foram 0,81, 0,74 e 0,79. Para fins de análise das técnicas de coleta de dados relacionadas à estatística descritiva, como tabelas de abundância e diagramas, foram utilizados MEV (modelagem de equações estruturais), testes $t$ e one-way ANOVA nos ambientes do SPSS e LISREL. software para testar as hipóteses. Os resultados mostram que OT e JP e OT estão relacionados ao CP de maneira positiva e estatisticamente significativa. Ademais descobriu-se que OT tem influências sobre o JP dos empregados dos departamentos de Esporte e Juventudes através do capital psicológico. Além disso, constatou-se que não houve relação estatisticamente significativa entre nenhuma das características demográficas e as principais variáveis do estudo.

Palavras-chave: Capital Psicológico, Confiança Organizacional, Desempenho no Emprego, Organizações Esportivas.

\section{Modelando el papel intermedio del capital psicológico en la relación entre la confianza} organizacional y el desempeño laboral en los departamentos de deportes y juventud de Irán

\section{Resumen}

El propósito de este estudio fue modelar el papel intermediario del Capital Psicológico en la relación entre la Confianza Organizacional y el Desempeño Laboral en los empleados de los departamentos noroccidentales de Desportes y Jóvenes de Irán. Esta investigación se considera un estudio descriptivo correlacional aplicado. La población del estudio incluyó a los 320 empleados completos de los departamentos de Desportes y Juventud ubicados en el noroeste de Irán. Entre la población, se seleccionaron 200 individuos como muestra de estudio mediante la aplicación del método de muestreo aleatorio estratificado. Los datos de investigación requeridos también se han recopilado mediante la aplicación de tres cuestionarios estándar de Organizational Trust (Alonen et al., 2008), Job Performance (Paterson, 1970) y Psychological Capital (Luthanz, 2007). Vale la pena mencionar que las validaciones de los cuestionarios fueron aprobadas por profesores de administración deportiva y la confiabilidad de los cuestionarios con alfa de Cronbach para los cuestionarios de confianza organizacional, JP y PC fueron $0.81,0.74$ y 0.79 . Para el análisis de los datos recopilados, se utilizaron técnicas relacionadas con estadísticas descriptivas tales como tablas de abundancia y diagramas SEM (modelado de ecuaciones estructurales), pruebas t y ANOVA unidireccional también se utilizaron en los entornos de SPSS y LISREL software para probar las hipótesis. Los resultados muestran que OT y JP y OT están relacionados con PC de manera positiva y estadísticamente significativa. Además, se descubrió que OT tiene influencias en el JP de los empleados de los departamentos de Desportes y Juventud a través del capital psicológico. Además, se descubrió que no existía una relación estadísticamente significativa entre ninguna de las características demográficas y las principales variables del estudio. 
Palabras clave: Capital psicológico, confianza organizacional, desempeño laboral, organizaciones deportivas

\section{Introduction}

Employees' Job Performance is defined as the general values expected from the behaviors of the employees by the organization. These behaviors are undertaken by each and every employee within a specific period of time while when there is a feeling that everyone is treated according to his/her competencies, there certainly would be higher levels of JP (Rousseau, 1998).

On the other hand, when there is organization trust amongst the employees and especially amongst managers and employees, this trust is most probably due to an organizational atmosphere in which employees feel like they are undertaking some beneficial and effective work; hence they achieve a feeling of personal growth which results in their tendency towards accepting works that provide them with an inner feeling of satisfaction. Many employees seek responsibility, growth opportunities, and job prosperity; or in other words are employed in healthy organizations. a main issue faced by modern organizations is lack of organization trust between employees and managers (Fathi, Leila and Talebzadeh, 2017).

In most modern organizations, especially the governmental organizations, there is a huge gap between the employees, managers, and their expectations. Because of this gap, decisions usually run into executive problems since employees will in most cases show rigidness against the execution of decisions whereas the managers also do not have confidence in the employees and exclude them from decision making processes. All together, these counts result in the generation of an atmosphere of lack of trust throughout the organization. The results of lack of trust can be emergence of behaviors such as rumor mongering, opposition, and slacking which all together drain the energy of organizations and increase the costs. In such an organization, talks about self-management, self-control, cooperation, creativity, total quality management and ... are futile while most of the efforts made towards improvement of performance and efficiency would meet no desirable result either. This is all because realization of organizational goals requires the cooperation of the members with each other and the most important way to 
facilitate cooperation is promoting mutual trust among the employees and between them and managers as well (Chavoshi, 2007).

Several definitions have been proposed for the term "trust"; however the definition provided by Rousseau et al., (1998) is most applicable in the domains of organizational behaviors. Based on this definition, trust is a psychological state comprising an intention to accept vulnerability based on positive expectations from the other partner. In other words, in an exchange relationship, one side of the relationship will act in the favor of the other side in the best way possible and with best considerations for mutual goals which will result in mutual realization of the interests of the both sides (Khorshidi and Yazdani, 2012).

On the other hand, it can be stated that nowadays, organizations are increasingly becoming aware of positivism and focusing on development of employees' advantages instead of stressing out their weaknesses. Nevertheless, organizations are also tirelessly trying to flatten the mentioned weaknesses. In other words, modern organizations seek ways to amplify their psychological capitals since they believe that positivism, being happy, and having a better feeling at work result in improved $\mathrm{OT}^{1}$ and JP. $\mathrm{PC}^{2}$ is defined as development of a positive individual psychological state (Avey et al., 2008). After more than a decade of research and theorizing, Luthanz (2012) identified four components that conform to these criteria in the best way: Hopefulness (will and or dynamic, or solution), Efficiency (self-confidence and believing in realization of goals), Flexibility (revival and going beyond the issues), and Optimism (having a positive view on events and expecting a positive future). Luthanz believed that when these components are combined, a high level structure would be formed which is referred to as PC (Luthanz, 2012).

In addition to the organizational functions of psychological capital, it has also been turned out that PC has also important applications in human resource management (HRM) and that it can be used for recruitment, promotion, and maintenance of the employees (Foruhar et al., 2013).

The importance of doing this research in the present conditions in Iran's sports system is both theoretical and practical. Theoretically, information about experts, researchers, and

\footnotetext{
${ }^{1}$ Organizational Trust

${ }^{2}$ Psychological Capital

@ $\odot$ Journal of Management \& Technology, Vol. 19. Extraordinary Edition, p. 4-23 Jul/Sep. 2019
} 
managers on how to reach a solution through psychological capital, organizational trust, and job performance of the employees of the sports and youth departments of northwest Iran is added. It is also very necessary to examine the role of the mediator of psychological capital in the relationship between organizational trust and job performance of the employees of the sports departments and youth in northwestern Iran. According to the above, this research aims to provide a desirable model for sport and youth departments in North West of Iran. Understanding what is the relationship between organizational trust and employees' job performance, taking into account the mediating role of psychological capital?

\section{Literature review}

\subsection{Psychological Capital}

The decision of moving away from disease model and illness to a new approach to looking at the world with positive qualities and traits of people started with the advent of positive psychology movement. This all started when the APA president Martin Seligman in 1998 in his presidential address to the association described his theme of speech to positive psychology. Positive psychology defined as the positive subjective experience. Seligman said the earlier approach of psychology to focus only on the mental illnesses and human disease is the product of history and was appropriate for that time. He never ruled out the need for the dysfunctional and disease model instead proposed that it is the time to shift over attention and course of study towards more positive approach. Positive psychology found its place in almost every domain of life like management, industries, health, sports etc. Fred Luthans (Luthans, 2002a, 2000b) pioneered the positive approach in organizational behavior by mapping out positive organizational behavior (POB), with its focus on building human strengths at work rather than only managing weaknesses. Luthans used Positive psychology or POB as a foundation point for the higher order construct which he called Positive Psychological Capital or simply PsyCap. PsyCap is a simply going beyond the human and social capital to actual self (who we are) (Avolio and Luthans, 2006: 147). He defined PsyCap as a developmental state of an individual characterized by self-efficacy, hope, resilience, and optimism (Luthans et al., 2007). Luthans said that these four components make up the positive state of Psychological 
Capital that can be measured, developed, and effectively managed for performance improvement in today's workplace' (Luthans, 2002b: 59).

\subsection{Organizational Trust}

Organizational trust presents the importance on both individuals and groups in the operation of an organization. To discuss the formation and development of organizational trust, researchers proposed multiple meanings and dimensions from different aspects. Anderson et al. (2012) organized organizational trust into five dimensions. Organizational trust was regarded as individual psychological state. Organizational trust was regarded as perceived experiences. Organizational trust was referred to the positive expectation and confidence in the properties of another party. Organizational trust was the intention to actively undertake risks. Organizational trust would change with overall situations. Cerne et al. (2014) divided organizational trust in schools into individual trust, which could be affected by the development experiences, type of personality, and cultural background of individuals, interpersonal trust, which stressed on trust generated from human interaction and depended on personal characteristics being dependable, competence trust, referring to organizational members being able to perform appropriate behaviors expected by the organization, and institutional trust, emphasizing the overall trust of organizational members (e.g. staff, directors, and principals in schools) in the organization (Narang Leenu \& Lakhwinder, 2011). Trust among people is regarded as interpersonal trust, which is divided into trust among colleagues, in supervisors, and in the entire organization. Cognition-based trust and affect-based trust are the major factors in interpersonal trust. The dimensions and definitions are described as below (Aburoub et al., 2011).

\subsection{Job Performance}

The most vital problem in a company is its Job Performance. This made researchers to research more and more (Shokrkon, 2001). They believe that performance is total expectation of organization from separate behavior samples of each person during specific period of time (Motowidlo, 2003). Job performance is a set of behavior which person show in relation to his job or, in other word, amount of efficiency gained due to the person job type (training, 
producing or servicing) (Rashidpoor, 2000). Job performance is the same person efficiency in his job according to his legal tasks and show amount of effort and successfulness of that person (Babu, et.al, 1997). It can be defined either as skill of person in doing his job and tasks.

Organizational theorists have divided job performance in two categories: task performance and dispositional performance. Task performance is defined as tasks and responsibilities of each person and related directly to all things that must be done by that person such as monitoring absent or present employee. Proper understanding of this needs definite standards. The other performance is dispositional which help organizational and social network to survive (Kwong, 2003). Matavidlo (2003) make differences between task performance and dispositional one. The first include parts that expressed in formal job and the latter include those behaviors effect on psychological, sociological and organizational aspects. Job performance can be studied by two aspects: hob creativity and job role.

In-role performance: behaviors related to tasks and responsibilities which are expressed in job description. Innovative performance: include creative solutions of employee for solving problems in work environment and the same as external role of performance which is important in organization success (Lee et al, 2010).

\section{Research background}

Results obtained by Shahbazi (2012) revealed the statistically significant effects of educational intervention on PC and job excitement; however it was turned out that PC had no statistically significant effects on JP.

Sampath et al., (2014) carried out a research and manifested that psychological capitals are positively and statistically significantly related to JP. On the other hand,

Bitmiş et al., (2013) carried out a study on the intermediary role of PC in the relationship between confidence in personal individual and job satisfaction (JS). In a research study titled as "Investigation of the Relationship between Psychological Capital, Job satisfaction, social anxiety, and OT among the Employees of Iran's National Excavation Corporation", and their 
results indicated that $\mathrm{PC}$ and job satisfaction have a positive and statistically significant correlation with organizational trust.

Sheisi et al., (2016) conducted a study titled as "Investigation of the Effects of PC on OT in the support atmosphere between the employees of Iran's Department of management and Planning" and concluded that the entire four components of PC have been statistically significantly effective on perceived support and OT as well.

Namvar and Beheshti (2014) carried out a study titled as "Investigation of the Relationship between PC and Commitment and, JP"; their results manifested that there exists a statistically significant relationship between PC and commitment and, JP of teachers.

\section{Hypothesis}

Main Hypothesis: There is a relationship between OT and JP with the mediating role of psychological capital.

$1^{\text {nd }}$ Sub Hypothesis: There is a relationship between OT and employee JP.

$2^{\text {nd }}$ Sub Hypothesis: The model of the role of intermediary role of PC in the relationship between OT and employee's JP is appropriate.

$3^{\text {nd }}$ Sub Hypothesis: There is a relationship between demographic factors with organizational trust, JP, and PC of employees.

\section{Methodology}

This research is considered as an applied descriptive-correlational study. The population of the study included the entire 320 employees of the departments of Sports and Youths located in the north-west of Iran. Among the population, 200 individuals were selected as the sample of study through the application of the random sampling method. The required research data have been also collected through the application of three standard questionnaires of OT Alonen et al., 2008, which includes 49 questions and three dimensions (horizontal, vertical and institutional trust) on the Likert scale of 5 options and JP Paterson, 1970 which includes 14 questions on the Likert scale of 4 options and PC Luthanz, 2007 which includes 24 questions on the Likert scale of 6 options. It is worthy of mentioning that the validities of the 
questionnaires were approved by sport management professors and reliability of questionnaires with Cronbach's alpha for the questionnaires of organizational trust, JP, and PC were $0.81,0.74$, and 0.79 . For the purpose of analysis of the collected data technics related to descriptive statistics such as abundance tables and diagrams have been used SEM (structural equations modeling), t-tests, and one-way ANOVA were also used in the environments of the SPSS and LISREL software for testing the hypotheses.

\section{Results}

In table 1 shows demographic characteristics of respondents.

Table 1

Demographic characteristics of respondents.

\begin{tabular}{|c|c|c|c|}
\hline & Valid & Frequency & Percent \\
\hline \multirow{2}{*}{ Gender } & Male & 118 & $59 \%$ \\
\hline & Female & 82 & $41 \%$ \\
\hline \multirow{3}{*}{ Age } & Between 22-30 & 70 & $35 \%$ \\
\hline & Between 31-40 & 95 & $47.5 \%$ \\
\hline & $\begin{array}{c}\text { More than } 40 \text { years } \\
\text { old }\end{array}$ & 35 & $17.5 \%$ \\
\hline \multirow{5}{*}{ Education } & Diploma & 13 & $6.5 \%$ \\
\hline & Associate degree & 26 & $13 \%$ \\
\hline & Bachelor & 114 & $57 \%$ \\
\hline & Master & 43 & $21.5 \%$ \\
\hline & Doctoral & 4 & $2 \%$ \\
\hline \multirow{4}{*}{ work experience } & $\begin{array}{c}\text { Between } 1 \text { to } 5 \\
\text { hours }\end{array}$ & 70 & $35 \%$ \\
\hline & $\begin{array}{c}\text { Between } 6 \text { to } 10 \\
\text { hours }\end{array}$ & 94 & $47 \%$ \\
\hline & $\begin{array}{c}\text { Between } 11 \text { to } 15 \\
\text { hours }\end{array}$ & 25 & $12.5 \%$ \\
\hline & More than 15 hours & 11 & $5.5 \%$ \\
\hline \multirow{2}{*}{ Marital status } & Single & 59 & $29.5 \%$ \\
\hline & Married & 141 & $70.5 \%$ \\
\hline
\end{tabular}

Main Hypothesis: There is a relationship between OT and JP with the mediating role of PC of the employees of the departments of Sports and Youths located in north-west of Iran.

The main research hypothesis has been investigated through the application of Path Analysis method based on figure number one and two. 


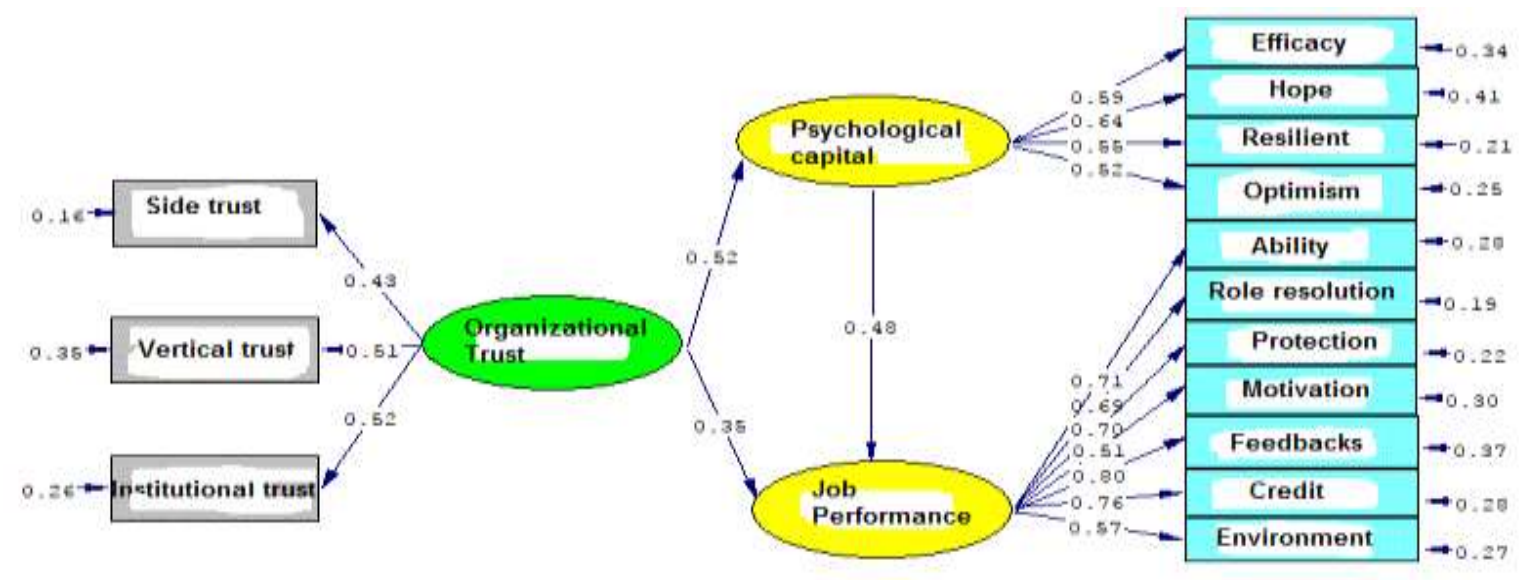

Ch1-Square $=117.66, d f=74, P-v a l u e=0.00388, \quad$ RMSEA $=0.043$

Figura 1. Fitness of the structural model of the study in standard estimation model

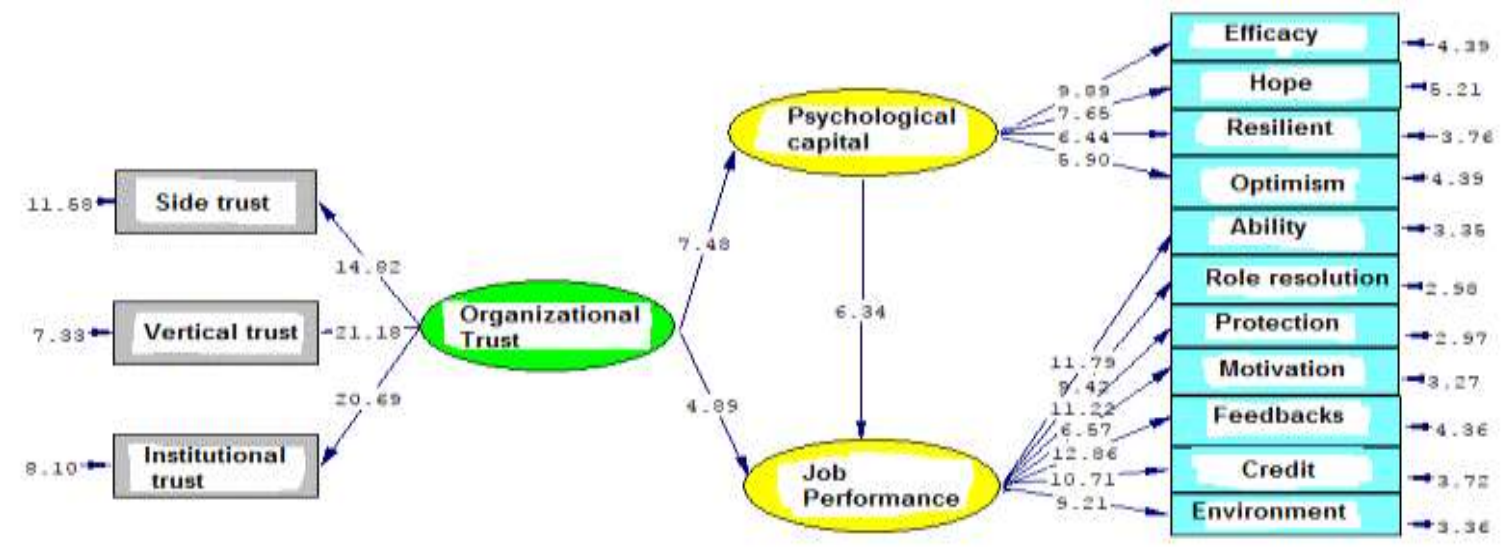

Chi-square $=117,66$, df $=74, p-$ value $=0.00388$, RMSEA $=0.043$

Figura 2. Fitness of the structural model of the study in significance model

As it can be observed, it has been turned out that OT is both positively and statistically significantly related to PC while PC too is in a statistically significant and positive manner 
related to organizational performance. In other words, OT leaves a positive and statistically significant effect on JP of employees of departments of Sports and Youths through PC. The standardized coefficient of indirect effects of OT on JP through PC is equal to 0.25; meaning that with a one SD unit increase of OT, JP increases for 0.25 SD under the mediation of PC. Hence the main hypothesis of the study is approved with a confidence of $99 \%$.

\section{$1^{\text {st }}$ Sub Hypothesis}

There is a relationship between OT and employee JP of the employees of the departments of Sports and Youths located in north-west of Iran.

The first, second, and the third su hypotheses have been investigated using the path analysis method according to diagrams number one and two. As you can see, the standard route coefficient between OT and JP is 0.35 with a calculated t statistic of 4.89 which is larger than 2.57; meaning that with a confidence of $99 \%$ it can be stated that there exists a positive and statistically significant relationship between OT and JP.

\section{$2^{\text {nd }}$ Sub Hypothesis}

The model of the role of intermediary role of PC in the relationship between OT and employee's JP is appropriate of the employees of the departments of Sports and Youths located in north-west of Iran.

Table 2

Estimation of fit indices for testing the properness of the structural model of study

\begin{tabular}{|c|c|c|}
\hline Index & $\begin{array}{c}\text { Approximate acceptance } \\
\text { range }\end{array}$ & Estimated value \\
\hline CMIN/DF & $<3$ & 1.59 \\
\hline RMSEA & $<0.08$ & 0.043 \\
\hline CFI & $0.8-1$ & 0.95 \\
\hline IFI & $0.8-1$ & 0.94 \\
\hline GFI & $0.8-1$ & 0.90 \\
\hline AGFI & $0.8-1$ & 0.88 \\
\hline
\end{tabular}

As you can see in table 1, the fitness indices obtained by the LISRELL software for the evaluation of the proposed structural model in the present study are located in the approximate 
range of acceptance; meaning that the data collected from the sample of study are to a great extent consistent with the proposed structural model. In the other words, the obtained values of good fit index show that the structural model proposed in the study is of a suitable fitness and hence it can be claimed that the proposed model is a roughly suitable model capable of explaining the structural relations between the variables present in the designed model. On this basis, the $2^{\text {nd }}$ subsidiary hypothesis is also accepted with a confidence of $99 \%$.

\section{$3^{\text {rd }}$ Sub Hypothesis}

There is a relationship between demographic factors with organizational trust, JP, and PC of employees of the employees of the departments of Sports and Youths located in northwest of Iran.

The relationships between the demographic features (gender, marriage status, education, experience, and age) and PC are tested through suitable measures and the results are shown in table 2. Results of the one-way ANOVA show that the relationships between the demographic features and PC are not statistically significant. In addition the results of the t-test show that the relationships between gender, marriage status and JP are not statistically significant either. Hence it can be claimed that employees with different demographic characteristics have had a roughly similar awareness about PC.

\section{Table 3}

The relationships between demographic features and PC

\begin{tabular}{|l|c|c|c|}
\hline \multicolumn{1}{|c|}{ Feature } & Test & Test Statistic & Sig. \\
\hline Gender & T-test & 0.005 & 0.996 \\
\hline Marriage & T-test & 1.007 & 0.315 \\
\hline Education & ANOVA & 0.712 & 0.585 \\
\hline Experience & ANOVA & 1.286 & 0.282 \\
\hline Age & ANOVA & 0.586 & 0.560 \\
\hline
\end{tabular}

The relationship between the demographic features and OT have been investigated and the results are shown in table 3. Results of the ANOVA test show that the relationships between education, experience and age, and OT are not statistically significant. In addition the results of t-test have shown that there exist no statistically significant relationships between gender, marriage status and OT. 


\section{Table 4}

The relationships between demographic features and OT

\begin{tabular}{|l|c|c|c|}
\hline \multicolumn{1}{|c|}{ Feature } & Test & Test Statistic & Sig. \\
\hline Gender & T-test & 1.345 & 0.180 \\
\hline Marriage & T-test & 0.493 & 0.623 \\
\hline Education & ANOVA & 0.327 & 0.860 \\
\hline Experience & ANOVA & 0.764 & 0.515 \\
\hline Age & ANOVA & 0.552 & 0.577 \\
\hline
\end{tabular}

The relationships between the demographic features and JP have been investigated and the results are shown in table 4. Results of the ANOVA test show that the relationships between education, experience and age, and JP are not statistically significant. In addition the results of t-test have shown that there exist no statistically significant relationships between gender, marriage status and OT.

\section{Table 5.}

The relationships between demographic features and JP

\begin{tabular}{|l|c|c|c|}
\hline \multicolumn{1}{|c|}{ Feature } & Test & Test Statistic & Sig. \\
\hline Gender & T-test & 1.843 & 0.089 \\
\hline Marriage & T-test & 0.713 & 0.477 \\
\hline Education & ANOVA & 0.924 & 0.451 \\
\hline Experience & ANOVA & 1.912 & 0.129 \\
\hline Age & ANOVA & 0.599 & 0.550 \\
\hline
\end{tabular}

\section{Discussion}

In order to justify the findings related to the main hypothesis of the study it must be said that when the employees and managers in organizations have confidence and trust in each other and the managers also have optimistic views about the employees, the employees would be provided with access to required data. In other words, there exists innerorganizational trust.

In such an organization, the personnel will surely be confident in their abilities for obtaining success in terms of their assigned tasks. In addition, at the time of facing inner organizational conflicts, they will not be exhausted; rather they will have high tolerance and they are would also be equipped with the skill to oppose the inner-organizational issues and 
their related tensions. In addition, when they face difficulties, instead of leaving the scene they will try to flatten the difficulty. On the other hand, it must be stated that employees' JP is an important variable in the context of industrial and organizational psychology in addition to being an important factor in progression and development of organizational objectives.

Hence, organizations have always been trying to identify and develop their human capitals one of which is psychological capital. In other words, it can be said that these people are able to successfully undertake their occupational tasks and move forward.

They will also act successfully in their journey towards success while having the required ambition for obtaining the pre-determined goals. Such employees are highly prone to success in their jobs and hence through creation of positive support and generation of suitable functional behaviors, the organization's environment would be influenced and its level of PC will improve as well.

As justification for the results of the $1^{\text {st }}$ subsidiary hypotheses it should be said that trust supplies the communications and talks within organizations and provides individuals with access for exchange of thoughts, and keeps various different behaviors alongside each other.

So when an organization is of a high level of trust, there would certainly be lower levels of conflicts, organizational instability, quitting, lack of motivation, rumors, strikes and etc. in addition, even after the working hours, employees will spend time on responding to the requirements of customers while they will also establish closer relationships with the managers and try to solve the conflicts between themselves, employees, and managers.

Therefore, employees would be serving in an organization in which the employees are highly motivated to do their jobs and as their confidence is promoted, they will show better JP levels.

Results of analysis of the third research hypothesis showed when there exists trust at different levels of the organization, one can witness honesty, competency, behavioral stability, loyalty, and truthfulness in that organization. In such an organization the employees will certainly feel more satisfied and hence will undertake their occupational tasks more hopefully and friendly. It can also be claimed that promotion of employees' JP will be effective on the improvement of their PC (PC) and results in realization of organizational goals. In fact one of the most important factors in improvement of JP is realization of determined goals. It is only in @@ $₫$ Journal of Management \& Technology, Vol. 19. Extraordinary Edition, p. 4-23 Jul/Sep. 2019 
trustful and healthy organizations that goals would be realized fully and according to predetermined plans without any disagreements, deviations, and etc. since the results of the study have shown that through psychological capital, OT is effective on JP; it seems that the departments of the Sports and Youths located in the north-west of Iran would pay more attention to the category of trust as well as promotion of JP of employees. In this way, the necessary means for promotion of PC would be provided in the former organizations. On this basis it seems necessary to implement the model proposed in the present study in the departments of Sports and Youths of north-west of Iran.

In order to provide justification for the results of the $3^{\text {rd }}$ subsidiary hypothesis it must be stated that in every organization there are employees with different genders, ages, education levels, and experiences; hence it cannot be strictly stated that those who are single or married are of more robust PCs and or someone who is younger or older is of better OT. Although, it is possible that some demographic features could be effective under special circumstances; but in the present study no statistically significant relations were found in this regard. This can be an idea for future studies to investigate the effects of demographic features on each and every variable studied in the present study.

Considering the overall findings of the study, the managers of departments are recommended to provide circumstances for enrichment of PCs. For example, through holding in-service courses and educational work-shops they should provide contexts that promote trust in the organization. Making efforts towards providing suitable education and training for the employees, supplication of the required resources for competent execution of tasks, facilitation of inner-organizational communications, and provision of healthy and intimate atmospheres filled with mutual respect and support can result in both improved OT and JP. The managers and authorities of the mentioned departments are also recommended to identify the factors that help with promotion of employees' JP. They should identify their organizations' psychological capacities and try to improve their employees' PC. Since the model provided in the present study is a suitable model, the departments of Sports and Youths located in north-west of Iran are recommended to pay more attention to the context of OT as well as the issue of promotion of employees' JP. In addition the necessary contexts for improvement of employees' trust and JP must be provided. In this sense, the requirements for promotion of PC would be supplied. 
On this basis it seems necessary to implement the model proposed in the present study in the departments of Sports and Youths of north-west of Iran.

The results of this study were compared with the findings of Fathi and Talebzadeh (1396) in a research entitled "The Relationship between Psychological Capital, Job Satisfaction and Social Anxiety with Organizational Trust in the Employees of the National Iranian Drilling Company" And the results showed that there was a positive and significant correlation between job satisfaction and psychological capital with organizational trust And with the study of Shis et al. (1395), in a study entitled "Investigating the Impact of Psychological Capital on Organizational Trust in our Supporting Grounds among Employees of Iranian Management and Planning Organization", it was concluded that all four components of psychological capital had a meaningful effect Understanded support and organizational trust.

Also, with Namur and Beheshti (1393) research, the research was conducted on the relationship between psychological capital and commitment with job performance and the results showed that there is a significant positive relationship between psychological capital and commitment with teachers' job performance. And by Khalifa Soltani et al. (1393), a research study entitled "The Impact of Managerial Positive Psychological Capital on Improving Employee Performance", conducted a study in Tehran's Nationwide Insurance Company. And the results showed that the positive psychological capital of managers leads to employee participation and improves their performance .

And also with the research of Deanat Nasab et al. (1393), in a study titled "The role of mediation of occupational stress in the relationship between psychological capital and employee job performance, psychological methods and models" The results showed that there is a negative and significant relationship between stress and job performance and there is a positive and significant relationship between psychological capital and job performance. Also, with the results of San \& Associates (2012) research on nurses in China, they concluded that psychological capital first boosted job placement and, consequently, increased job performance.

\section{Conclusions}


Psychological capital is a person's psychological state that governs the interactions between individuals and leads to economic and social development. It should be acknowledged that psychological capital includes common values and customs for social guidance that manifests itself in the private relationships of individuals, trust and a collective sense of civic responsibility, and transforms society into something more than a set of individuals. In fact, this concept refers to the relation between members of a network as a valuable resource, which creates the norms and mutual trust, which accomplishes the goals of the members. Nowadays, psychological capital is considered as one of the components of wealth of nations and sustainable development and one of the tools of capacity building in organizations, is a tool for preventing and reducing social damages and a factor in the success of social welfare programs and promoting individual and social health and health of organizations Which itself can be influenced by a set of variables such as organizational trust and employee performance Which can ultimately affect the improvement of organizational health. Therefore, it is suggested that the importance and role of this factor in the management of sports and youth departments of these provinces should be carefully considered and the policies and context necessary to improve it.

\section{References}

Aburoub, A.S. Hersh, A.M. \& Aladwan, K. (2011). Relationship between internal marketing and service quality with customers' satisfaction. International Journal of Marketing Studies, $3(2), 107-118$.

Anderson, P. Cooper, C. Layard, R. Litchfield, P. \& Jane-Llopis, E. (2012). Well-being and global success-A report repared by the World Economic Forum Global Agenda Conuncil on health \& well-being. World Econ Forum, 5-8.

Avey, J.B., Wernsing, T.S. and Luthans, F. (2008). Can Positive Employees Help Positive Organizational Change? Impact of PC and Emotions on Relevant Attitudes and Behaviors. The Journal of Applied Behavioral Science, 44, 48-70.

Babu, A.R. Singh, Y.P. Sachdeva, R.K. (1997).” Managing human resources within extension", In: Burton E. Swanson, Robert P. Bentz, Andrew. 
Bitmiş, MG. and Ergeneli, A. (2013). The role of PC and trust in individual performance and job satisfaction relationship: A test of multiple mediation model. Procedia - Social and Behavioral Sciences, 99, 173-179.

Cerne, M. Nerstad, C.G. Dysvik, A. \& Škerlava, M. (2014). What goes around comes around, Knowledge hiding, perceived motivational climate, and creativity. Academy of Management Journal, 57(1), 172-192.

Chavoshi, Seyed Mohammad Hussein. (2007). Investigating and studying the relationship between managers 'emotional intelligence and their subordinates' trust. Master's thesis, University of Tehran.

Diant Nasab, Medina. (2013). The Explanation of the Role of Interpersonal Stress of Job Stress in the Relationship between Psychological Capital and Job Performance of the Employees of the Dasht Gaz Group of Gachsaran Oil and Gas Company. Master's Thesis, Islamic Azad University, Marvdasht Branch.

Fathi, Leila. Talebzadeh Shooshtari, Marzieh. (2017). The Relationship between Psychological Capital, Job Satisfaction and Social Anxiety with OT in the Employees of the National Iranian Drilling Company. Journal of Social Psychology, 11(42), 21-13.

Foruhar, Mohammad. Maleki, Ehsan. Roozbehani, Shiva. Shah Mohammadi, Neda. (2013). Management of Organizational Psychology: A New Approach to Creating Competitive Advantage. Second National Conference on Modern Management Sciences, Gorgan.

Khalifa Soltani, Heshmat; Governor, Farzaneh and Sahat, Saeed. (2014). Effect of Positive Psychological Capital of Managers on Improvement of Employees' Performance, a Study on the Nationwide Insurance Company of Tehran. Iranian Journal of Management Sciences, 9(33), 68-47.

Khorshidi, Seddiq. Yazdani, Hamid Reza. (2012). Study Relationships Between Trust, Conflict and Feeling of Organizational Ownership Considering the Impact of Transformation. Transformation Management Research Journal, 4 (7), 61-90.

Kwong, J. \& Cheung, M. (2003).” Prediction of Performance Facets Using Specific Personality Trait in the Chinese Context". Journal of vocational behavior, 6(4), 45-61.

Luthans, F. ( 2012). Psychological capital: Implications for HRD ، retrospective analysis ، and future directions. Human Resource Development Quarterly, 23(1), 1-8.

Luthans, F. (2002). The need for and meaning of positive organizational behavior. Journal of Organisation Behavior, 23, 695-706.

Luthans, F. Avolio, BJ. Avey, JB. Norman, SM. (2007). Positive Psychological Capital: Measurement and Relationship with Performance and Satisfaction. Personnel Psychology, $60,541-572$. 
Motowidlo, J. S. (2003). " Job Performance. Handbook of Psychology", Industrial and Organizational Psychology,12, 39-55.

Namvar, Yousef. Beheshti, Serieh. (2014). Investigating the Relationship between PC and Commitment with JP, Journal of Future Studies in Management, 25(101), 21-13.

Narang, L. \& Lakhwinder, S. (2011). Human resource practice and organizational trust, An empirical study. Paradigm, 15(1/2), 66-71.

Olivia, F. Lee, James A. Tan, Rajeshekhar Javalgi. (2010). "Goal orientation and organizational commitment: Individual difference predictors of job performance". International Journal of Organizational Analysis, 18(1), 129-150, https://doi.org/10.1108/19348831011033249.

Rashidpoor, M. (2000)." Correlation analysis of organizational commitment and job performance of calculating organization personnel". M.Sc. Thesis, Governmental Management Education Center, 180.

Rousseau, DM. Sitkin, SB. Burt, RS. Camerer, C. (1998). Not so different after all: a crossdiscipline view of trust. Academy of Management Review, 23(3), 393-404.

Sampath Kappagoda, UW. Othman, H.Z.F. and De Alwis, G. (2014). PC and JP: The Mediating Role of Work Attitudes. Journal of Human Resource and Sustainability Studies, 2, 102-116.

Shahbazi, Sepideh. (2012). The Impact of PC Training on JP and Job Excitement in Kayson Employees. Master thesis, Shahid Chamran University of Ahvaz.

Sheisi, Gholamreza. Khosh Sima, Reza. Ghaffari Fard, Mohammad. (2006). The effect of PC on OT in our advocacy atmosphere between the staff of the Organization for Management and Planning. Magazine Management Development, Special Letter, 2, 221-228.

Shokrkon, Hossein. Neissi, Abdolkazem. Na'ami, Abdolzahra. Maehrabizadeh honarmand, Mahnaz. (2001)."The investigation of relation between job satisfaction with social behavior and job performance in some factories in Ahvaz", psychological and pedagogical magazine, Shahid Chamran university, 4(8), 13-24.

Sun, L, Zhang, Z، Q, J. \& Chen, Z. (2011). Empowerment and creativity: A cross-level investigation. The Leadership Quarterly, 11, 257-278. 